\title{
Information And Communication Technology As A Pedagogical Tool In Teacher Preparation And Higher Education
}

Chien-Hui Yang, Nanyang Technological University, Singapore Pei-Wen Tzuo, Nanyang Technological University, Singapore

Heidi Higgins, University of North Carolina Wilmington, USA

Clarence Puay Yon Tan, Nanyang Technological University, Singapore

\begin{abstract}
Under the current trend of globalization and economic dynamics, the accountability of our educational systems is being seriously tested. In response to the demands of the future, the Ministry of Education (MOE) in Singapore has wisely proposed several initiatives to promote the integration of Information and Communication Technology (ICT) in education, and to increase the competitiveness of the workforce by emphasizing inquiry-based learning, higher order thinking, and problem solving (i.e., Thinking Schools Learning Nation, Students' Effective Engagement and Development). This study asserts that these two goals, rather than being mutually exclusive, are highly related. Research has shown that integrating technology in teaching and learning can have positive influences on higher order thinking, students' motivation, inquiry-based learning, attitudes, achievement, and peer interactions in the classrooms (Bennett, 2001; Schofield, 1995).
\end{abstract}

Keywords: Information and Communication Technology; WebQuest; Pedagogical Tools

\section{INTRODUCTION}

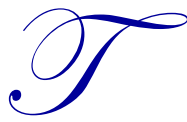

his study further proposes to use WebQuest to promote higher order thinking and ICT integration in early childhood and special education teacher preparation. Developed by Dodge (1995), WebQuest is an inquiry-based teaching tool, in which students of all ages and levels participate in an authentic task that uses pre-designed, pre-defined internet resources, though other print resources can also be used. Research has documented that WebQuest has effectiveness in promoting student engagement, motivation, connecting to authentic contexts, critical thinking, higher order thinking, literacy skills, and Information and Communication technology (ICT) integration (Abbitt \& Ophus, 2008; Ikpeze \& Boyd, 2007; Kanuka, Rourke, \& Laflamme, 2007; Lara \& Reparaz, 2005). It should be noted that most studies were conducted on the subject areas of Math, literacy, or science. In the Singapore context, many local teachers still have not heard of WebQuest or learned about using WebQuest in their teaching.

This research project poses three research questions: (1) Is WebQuest a useful tool to enhance teacher's critical thinking, motivation and engagement, and creativity? (2) Does the use of WebQuest in teacher preparation foster stronger desires for teachers to integrate ICT in teaching? (3) Does WebQuest foster content-specific learning in teacher preparation (namely accommodating individual difference and implement Universal Design for Learning for children with special needs)?

Twenty eight in-service special education teacher and early childhood teachers participated in this study. This study involves two levels of participation, (A) teachers experienced WebQuest activities developed by the instructors as users of WebQuests (such as creating tactile children's books for children with special needs), and (B) teachers were trained to create WebQuest for their students in K-12 classrooms. 
After experiencing these two levels of participation, teachers responded to a survey questionnaire. Results have shown that teachers rated preferably for using WebQuest as an ICT integration tool in their classrooms.

Specifically, one hundred percent of teachers participated in our study agreed that WebQuest have helped teachers to learn more ways to incorporate technology in teaching and learning (71.4\% strongly agree, and $28.6 \%$ agree). After learning about WebQuest in class, they also expressed that they would like to use more technology and web resources in teaching in the future (39.3\% strongly agree and $60.7 \%$ agree). Moreover, one hundred percent of teachers thought that WebQuest has promoted their critical thinking abilities (46.4\% strongly agree, and $53.6 \%$ agree). All of the participants also felt WebQuest fostered their creativity (53.6\% strongly agree and $46.4 \%$ agree), motivation and engagement (46.4\% strongly agree, and $53.6 \%$ agree).

This paper will not only introduce the research findings, but will also share sample projects (tactile sensory books) developed by the teachers as part of the WebQuest activities.

\section{BACKGROUND}

According to Marc Prensky (2001), today's learners are defined as "digital natives" because they were born into the high-tech digital ages and surrounded by computers, internet, online social network, cell phones, and video games. They think and process information differently than the previous generations of "digital immigrants", a generation of individuals who were not born into the digital ages but had to learn to use and cope with the advances of technology in the midst of their career (Prensky, 2001). "The single biggest problem facing education today is that our Digital Immigrant instructors, who speak an outdated language (that of the pre-digital age), are struggling to teach a population that speaks an entirely new language" (Prensky, 2001, p.2). Indeed, as the technology advances in all aspects of our daily lives, our education system is often slow to adapt and change. The generation gap between "digital native" and "digital immigrant" can be manifested in how teachers and students interact and engage in teaching and learning in our classrooms, from kindergarten through higher education, and even into teacher preparation programs. It is a major concern whether the needs of "digital natives" can be met by educators who are largely "digital immigrants". In K-12 education, research has shown that teachers do not regularly use technology during their teaching or integrate technology in their classrooms (Bielefeldt, 2001; Wang, Ertmer, \& Newby, 2004). Under the current trend of globalization and economic dynamics, accountability of our educational systems is being seriously tested. The essential question posed is, are our teachers and schools ready to carry out the mission to meet the demands of the future by preparing our young learners with the knowledge, skills, and innovation capabilities necessary to advance our competitiveness globally?

One powerful solution to bridge this worrisome generational gap, as the Ministry of Education (MOE) in Singapore has wisely proposed, is the use of Information and Communication Technology (ICT) to improve teaching and learning to enhance the competitiveness of our future work force. The other is to increase the competitiveness of workforce by emphasizing inquiry-based learning, higher order thinking, and problem solving. This study asserts that these two goals, rather than being mutually exclusive, are indeed highly related. After all, research has shown that integrating technology in teaching and learning can have positive influences on students' motivation, inquiry-based learning, attitudes, achievement, and peer interactions in the classrooms (Schofield, 1995).

\section{ICT Integration in Higher Education and Teacher Preparation}

The literature strongly supports the importance of modeling the use of technology by instructors in higher education and teacher preparation programs (Widmer \& Amburgey, 1994).

As the National Standards for Technology in Teacher Preparation developed by the International Society for Technology in Education (ISTE) strongly asserted, all teachers need to acquire competencies in basic computer technology skills and application of technology for classroom instructions. In helping our teachers become technology literate, the missions of our teacher preparation programs not only include the delivery of the content knowledge and pedagogies in the subject domains, but also modeling the capabilities in integrating technology in teaching and learning. Few teacher preparation programs, based on Wise et al., (1997), met all of those technology 
standards. Further, a nation-wide survey (Moursund \& Bielefeldt, 1999) has shown that most faculty members at the teacher preparation programs do not model ICT skills in their teaching. Not surprisingly, their study also found that student teachers in K-12 classrooms do not regularly use technology during their field experiences, and do not work with supervisors who can advise them on ICT use when ICT is available in such settings. As our higher education teacher preparation programs fall short in technology integration ourselves, it is unrealistic to ask our preservice and in-service teachers in K-12 levels to become tech-savvy. Indeed, literature has supported the importance of modeling the use of technology by instructors in higher education and teacher preparation programs full-heartedly (Widmer \& Amburgey, 1994). Many researchers also called upon the need for research to focus on the integration of instructional technology by faculty in preservice teacher education (Pellegrino \& Altman, 1997; Wild, 1996). Research has shown that integrating technology in teaching and learning has positive influences on students' motivation, attitudes, achievement, and peer interactions in the classrooms (Schofield, 1995). Particularly, when teachers were exposed to the use of technology in teacher preparation courses, they were more likely to use the technology in K-12 classrooms and developed more positive attitudes toward integrating technology into their teaching (Wheatley, 2003; Gulbahar, 2008). On the other hand, lack of use and integration of technology in teacher preparation programs may result in technology anxiety of preservice teachers and beginning teachers (Wild, 1996).

In order to promote the use of technology in curriculum and instruction by K-12 teachers, the faculty in teacher preparation programs must model the appropriate use of technology in content instruction. This argument is in sync with Confucius' famous saying, "I hear and I forgot, I see and I remember, I do and I understand." Modeling the integration of technology in higher education classrooms is the key to promote the use of technology by K-12 teachers for today's learners who are "digital natives."

\section{WebQuest: A Technology and Pedogogical tool for Universal Design for Learning}

While the integration of technology in education is highly valued, some researchers also cautioned that "Technology alone does not guarantee solutions to educational problems" (Hassanien, 2006, p.42). In respond to this caution of over-relying on technology to solve educational problems, this research project proposed the use of WebQuest in teaching and learning because WebQuest, though a technology itself, is also a pedagogical tool to apply Universal Design for Learning. In other words, WebQuest is not only a technology we can integrate into curriculum and instruction, it is also a pedagogical tool that intends to promote student engagement, inquiry-based learning, and accommodate diverse learners.

This research study proposes an innovative application of the WebQuest, in a teacher preparation Master's degree course (Early Intervention) at the National Institute of Education, Nanyang Technological University at Singapore.

Developed by Dodge (1995), WebQuest is an inquiry-based teaching tool, in which students of all ages and levels participate in an authentic task that use pre-designed, pre-defined internet resources, though other print resources can also be used. Learners will put the focus on gathering, summarizing, synthesizing, and evaluating the information within clearly defined parameters in order to accomplish an authentic task set by the instructor. WebQuest takes a problem-solving approach and exhibits a clear structure that guides the learning processes and interactions (Dodge, 2001), and can be used for different subject areas across age levels, from young children to adult learners (Ezell, Klein, Hines, \& Hall, 2003). WebQuest demonstrated a project-based learning that helps students to complete authentic projects integrating technology in their learning (Garry, 2001) across ages.

\section{WebQuest in ICT integration in Education}

WebQuest includes 6 standardized components, namely (A) introduction, (B) tasks, (C) processes, (D) resources, (E) evaluations, and (F) Conclusion. Some WebQuests also add two more components, credits and teacher's page, as appropriate.

Created by teachers, WebQuest can be posted and published on the Web, or simply created in a power point format to be presented to the students. In other words, WebQuest allows teachers with a wide range of technology competencies to create lessons and activities for teaching and learning. 
WebQuest serves as an ICT integration tool for the following two reasons. First, from teaching point of view, during the process of creating a WebQuest, teachers are required to search for suitable internet resources that are relevant to the topic and learning content, such as video clips, relevant web sites, educational software, and educational games, and multi-media resources. They are also advised to present their learning content through technology, such as using video clips, audio sound clips, and graphics. Consequently, teachers learn to gather and use web resources in their teaching as a crucial part of instructional delivery. Second, from learning point of view, students are required to use the internet resources teachers provided in WebQuest to complete their learning tasks, process information, analyze, synthesize, and produce the desirable outcomes specified by the teachers. Students may also be required to use technology skills to accomplish WebQuest learning tasks, such as creating a video clip, a website, or playing an educational game online. Both teachers and students improve their ICT experiences and skills through the use of WebQuest in teaching and learning. ICT becomes an integrated part of teaching and learning through the use of WebQuest.

WebQuest as a pedagogical tool to promote student engagement, higher order thinking, and accommodating individual difference

WebQuest, rooted in Constructivism, is an inquiry-based activity. WebQuest applies a constructivism learning approach that allows learners to engage in higher order thinking skills and to build meaningful learning experiences in meaning making (Lahaie, 2008). As Bennett (2001) asserted, "With the inclusion of technology into learning environments, the role of the teacher changes from instructor to guide. The learning process has become inquiry based. The instruction is student centered and the learner is actively engaged" (p. 9). WebQuest promotes inquiry-based learning by assisting learners to organize ideas, explore and evaluate information, analyze and synthesize data, and communicate findings and conclusions (Lamb \& Teclehaimanot, 2005).

Higher order thinking and learning can be viewed as an ability to compare, explain, contrast, analyze, apply, theorize, generalize, hypothesize, and reflect (Biggs, 2003). The benefit of WebQuest in promoting higher order thinking skills is commonly recognized (Allen \& Street, 2007; Lara \& Reparaz, 2005; Lim \& Hernadez, 2007). Gohagan (1999) asserted that WebQuest improves learners' problem solving skills by requesting learners to expand and refine their knowledge, and integrate their skills in order to accomplish an authentic task. While WebQuest offers authentic learning tasks for learners, resources and processes in accomplishing tasks are provided, but there is no one correct way to complete the task. Consequently, students are required to find their own paths based on their learning preferences, goal setting, and individual differences to achieve the task, which is a great opportunity for problem solving and higher order thinking. Participants in one study asserted that the most meaningful part of WebQuest experiences was having the opportunities to develop critical thinking and creativity (Lim \& Hernadez, 2007). Research has shown that WebQuests were more effective than some other activities at supporting a higher cognitive presence and thinking compared to other strategies (Kanuka, Rourke, \& Laflamme, 2007). Moreover, while WebQuest is used in junction with cooperative learning approaches as this project proposes, the problem solving skills of learners can be further enhanced (Lara \& Reparaz, 2005).

While the principle of Universal Design is widely used in Architecture (e.g., the use of automatic doors to make buildings accessible for individuals with different mobility abilities), the application of these principles in the form of Universal Design for Learning (UDL) in education is fairly recent (Council for Exceptional Children, 2005; Rose \& Meyer, 2002; Rose, Meyer, \& Hitchcock, 2005). Derived from neuroscience and the advanced knowledge of individual differences, Universal Design for Learning (UDL) is intended to design curriculum in ways that accommodate all learners with different learning styles, ability levels, backgrounds, and preferences (Rose \& Meyer, 2002). As a blueprint for teaching every student, Universal Design for Learning features the following three principles: (1) multiple means of representation of information and concepts, (2) multiple means of engagement of learners, and (3) multiple means of expression and performance (Rose \& Meyer, 2002). To implement UDL, teachers are to change their way of teaching by offering multiple ways to present the content knowledge, promoting student engagement, and offering alternative methods for students to express what they have learned. Examples of UDL teaching tools include but not limited to: WebQuest, guided notes, portfolio, graphic organizers, text to speech synthesizer, and tiered assignments. It is realized that UDL can benefit all types of learners with high, average, and low abilities. 


\section{Use of WebQuest in higher education teacher preparation programs}

At K-12 levels, research has shown that WebQuest benefited students' engagement, higher order thinking, motivation, connection to authentic contexts, critical thinking, problem solving, collaborative learning, and literacy skills (Ikpeze \& Boyd, 2007; Lara \& Reparaz, 2005). A recent search of the webquest.org database showed more than 1700 user-contributed WebQuest activities in all K-12 curricular areas as well as materials for adult learners and higher education. It should be noted that compared to the large number of user-contributed WebQuest activities on the internet, in the literature, the number of research studies on WebQuest is significantly smaller.

"Technology use in teacher education provides a complex challenge for teacher educators, both at a pedagogical issue and as a matter of effectively integrating uses into method course" (Bates, 2008, p.10). Given the emphasis on integration of instructional technology in the higher education teacher preparation programs, several studies investigated the effect of using WebQuest to training pre-service and in-service teachers across various content areas. Research has shown that WebQuest enhanced problem-solving skills, higher order thinking, motivation, creativity, critical thinking, active learning, connection to authentic contexts (Abu-Elwan, 2007; Allan \& Street, 2007; Lim \& Hernandez, 2007) and assisted in bridging the theory to practice gap (Lim \& Hernandez, 2007). Abu-Elwan (2007) used WebQuest to enhance the Mathematical Problem-Posing skills of pre-service teachers. Compared to the control group of teachers who do not experience WebQuest in their learning process, the teachers who experience WebQuest have significantly higher scores on problem posting skills. Bates (2008) used WebQuest to enhance pre-service teachers' exploration of the Internets as an authentic context in social science education. She stated that one benefit of using WebQuest in teacher preparation course is to help teachers to learn about the potential and challenges of using WebQuest in authentic contexts with children in K-12 classrooms. Lim \& Hernandez (2007) used the WebQuest with Master's students in family therapy programs to foster higher order analytical and synthesis skills. Results demonstrated that WebQuest was perceived as an effective technological tool. Though Master's students found WebQuest project difficult, they highly valued this learning experience and found the project meaningful in bridging the theory to practice gap. They also indicated that WebQuest is helpful in promoting global thinking, motivation, creativity, critical thinking, and interest. In Hassanien's (2006) study, preservice teachers found WebQuest stimulating and useful for their academic learning. All teachers agreed that WebQuest tasks helped them to take an active role in their learning. It should be noted that most studies were conducted on the subject areas of Math, literacy, or science; few studies have focused on teacher preparation in early childhood education and special education.

This study argues that in order to ensure pre-service and in-service teachers achieve curricular specific goals (such as inquiry based learning, higher order thinking, collaborative learning, Universal Design for Learning), instructors in teacher preparation programs must teach and model what we preach for two reasons. First, when the instructors model the recommended practices and instructional strategies, K-12 teachers have opportunities to observe these practices at work, which may in turn enhance their understanding and skills in application of the teaching practices. Second, K-12 teachers have opportunities to experience the benefits of implementing the recommended practices as learners, in comparison to traditional teacher-directed paper-pencil teaching methods. The positive learning experiences may motivate them to adopt the recommended practices and strategies in their classrooms. These arguments are in sync with Confucius' famous saying, "I hear and I forgot, I see and I remember, I do and I understand.”

In Singapore, few research studies have focused on establishing WebQuest as an evidence-based practice in enhancing teaching and learning or a pedagogy promoting Universal Design for Learning and inquiry based learning. Examples of exceptions investigating the use of WebQuest in Singapore local contexts include studies and papers developed by Chang (2004), Kheng (2003), and Lim (2006). While Kheng's (2003) and Lims' (2006) papers simply served as the introduction of the WebQuest as a teaching tool, Chang's (2004) paper reported a research study at the local context. Chang (2004) used WebQuest in Secondary school geography in Singapore to enhance student motivation and project based learning. Chang's study has revealed mixed results and was non-conclusive. These papers strongly signal the need for empirical research on WebQuest in Singapore local contexts, due to the limited number of research conducted and the need to validate the effects of WebQuest as a teaching strategy that promotes higher order thinking. 


\section{Significance of the Study}

Singapore's Ministry of Education (MOE) has launched important initiatives to anticipate the needs of the future and to prepare our young generation to meet those needs. Examples of these initiatives include: Information and Communication Technology (ICT) master plans, the FutureSchools@ Singapore programme, Thinking Schools Learning Nation (TSLN), and Students' Effective Engagement and Development (SEED). The mater plans for Information and Communication Technology (ICT) in education are intended to strengthen the integration of ICT into curriculum and instruction, provide practice-based professional development in ICT, and distribute best practices and successful innovations. Under the collaboration of Ministry of Education (MOE) and Infocomm Development Authority of Singapore (IDA), several consortia have been selected to design and deploy next generation infocomm-enabled solutions for selected FutureSchools, with an emphasis on problem-based, inquirybased authentic learning through the integration of technology in teaching and learning. In addition, initiatives such as Thinking School Learning Nation (TSLN) and Students' Effective Engagement and Development (SEED), aim to enhance hands-on learning and the quality of teaching and student engagement in Singapore. These initiatives prompted teachers to move away from the traditional teacher-directed paper-pencil teaching methods. Rather, inquiry-based learning, higher order thinking, hands-on learning are set as the future direction of education and are strongly encouraged.

In spite of MOE's efforts in promoting higher order thinking and inquiry-based learning, Singapore has not met the goal of transiting into an inquiry-based learning country (Tan \& Ng, 2005). Several studies suggested that teachers faced the dilemma of preparing children to perform well on traditional paper-pencil examinations, plus meeting the demands of MOE initiatives in promoting higher order thinking, problem-solving, and hands-on learning (Dixon et al., 2008; Wright \& Gan, 2006). The evidence above further stresses the importance of conducting this research project to model inquiry-based learning and promote higher order thinking for K-12 teachers. It is difficult to change the way teachers teach without the opportunities to observe new teaching practices at work. If inquiry-based learning and higher order thinking is demonstrated in teacher preparation courses, K-12 teachers will get a chance to embrace these practices as a natural way of teaching and learning, rather than hypothetically, as exists only in theory and textbooks. Moreover, Universal Design for Learning and WebQuest strategy helps teachers to accommodate students with different learning styles and special needs in the general education classrooms. These strategies are crucial content knowledge for all K-12 teachers to acquire, so that they can develop disability-awareness, respect for individual differences, and better readiness to include students with special needs in their classrooms.

Again, without teaching what we preach, instructors in teacher preparation programs can't effectively improve K-12 teaching practices by promoting higher order thinking and accommodating students with special needs in general education classrooms.

\section{Purpose of the Study}

The purpose of this study is to use WebQuest to promote higher order thinking and ICT integration in teacher preparation for early childhood and special education teachers in Singapore. This study involves participants into two levels of participation, (A) teachers experienced WebQuest activities developed by the instructors as users of WebQuests (such as creating tactile children's books for children with special needs), and (B) teachers were trained to create WebQuest for their students in K-12 classrooms.

\section{RESEARCH METHODS}

\section{Research Questions}

This research project poses three research questions: (1) Is WebQuest a useful tool to enhance teacher's critical thinking, motivation and engagement, and creativity? (2) Does the use of WebQuest in teacher preparation foster stronger desires for teachers to integrate ICT in teaching? (3) Does WebQuest foster content-specific learning in teacher preparation (namely accommodating individual difference and implement Universal Design for Learning for children with special needs)? 


\section{Participants}

This research study was conducted in a Master's course, Early Intervention, within higher degree programs at National Institute of Education, Nanyang Technological University, Singapore. This elective course is open to both early childhood teachers and special education teachers. Twenty-eight early childhood teachers and special education teachers were recruited to participate in this study.

\section{Procedures and Instrumentation}

\section{Procedures}

Twenty eight in-service special education teacher and early childhood teachers participated in this study. This study involves two levels of participation, (A) teachers experienced WebQuest activities developed by the instructors as users of WebQuests (such as creating tactile children's books for children with special needs), and (B) teachers were trained to create WebQuest for their students in K-12 classrooms. After experiencing these two levels of participation, teachers responded to a survey questionnaire. Results have shown that teachers rated preferably for using WebQuest as an ICT integration tool in their classrooms.

\section{Phrase A. Teachers as users of WebQuest}

The instructor (author of the paper) developed a WebQuest for early childhood teachers and special education teachers to experience as part of class activities and assignments.

Three authentic tasks incorporating internet resources were posed as class activities:

1. Task 1: Conduct a debate on a case study concerning whether to implement full inclusion for Jake, a young child with special needs.

2. Task 2. Observe an inclusive preschool classroom (through video footage) in the United States, and design a slogan and an advertisement to advocate for inclusion for parents and teachers in Singapore context.

3. Task 3. Conduct a library search with a focus on journal articles along with web sources. Translate the information you learned into one of the following products with a partner: (i) Create a children's book on children with targeted disabilities. The book can be for any age groups (from infants, toddlers, preschoolers, to primary and have to include multi-media and tactile/textural materials (such as beads, objects, sand papers, etc.) so the book can be used for children with disabilities as well as typical children. Imagine using this book in your own classroom to promote disability awareness or social interactions. (ii) Create a brochure on instructional strategies to work with children with targeted disabilities. The target audience of the brochure can be for teachers or parents.

After the creation, role-play and demonstrate how you would use the book/brochure in real life situations with your students or parents.

\section{Phrase B. Teachers receive training to create WebQuests for their students in K-12 classrooms}

Teachers received a 3 hour training session on WebQuest. They learned what a WebQuest is and received training in creating a WebQuest (in a group of 3-4 members) from scratch (Yang, Komara, \& Tzuo, 2011). The instructor guided them through the processes of selecting a topic, designing authentic learning tasks, integrated learning objectives, look for web resources, designing assessment rubrics, and breaking tasks into smaller steps. These WebQuest activities were conducted over a period of thirteen-weeks.

\section{Instrumentation and Data Collection}

A survey questionnaire were developed as an instrument for this study. The survey contained 20 questions using a 5 point rating scale (Score I: don't know, Score 2: Strongly disagree, Score 3: disagree, Score 4: Agree, Score 5: Strongly agree). Based on previous studies (Yang, Tzuo, \& Komara, 2011), a large percentage of teachers 
in Singapore do not know what WebQuest is. In order to measure the effects of training, the scale designed the scale rating 1 as "I don't know" to accommodate the cultural differences in the exposures of WebQuest for Singapore participants.

Teachers were asked to complete this survey on WebQuest at the beginning of the semester prior to their exposures to WebQuest activities and training as a pre-test. After teachers completed the WebQuest activities and training, they completed the survey again as a post-test.

\section{Data Analysis}

The pre- and post-surveys completed by each participant were matched up in preparation for conducting SPSS t-test as quantitative data analysis. The data collected in the study was then compiled into the SPSS software. The percentage of each rating for each question is calculated and reported. In addition, paired t-test was conducted to investigate whether the difference of teachers' ratings in post-test and pre-test were statistically significant.

\section{RESULTS AND DISCUSSION}

\section{Demographics}

Among 28 participants, $100 \%$ are female teachers. In terms of ethnical background, $71.4 \%$ of teachers are Chinese, 25\% are Indian, and 3.6\% are listed as others (3.6\% are Hispanic/Latino). Most (61.5\%) participants are teaching at the Preschool/Kindergarten level, 23.1\% at Primary Grade 1 and 2 levels, 23.1\% at Primary Grade 3 and above levels, and $11.5 \%$ are teaching in Special Education School settings.

\section{Research Questions}

This research project poses three research questions:

1. Is WebQuest a useful tool to enhance teacher's critical thinking, motivation and engagement, and creativity?

2. Does the use of WebQuest in teacher preparation foster stronger desires for teachers to integrate ICT in teaching?

3. Does WebQuest foster content-specific learning in teacher preparation (namely accommodating individual difference and implement Universal Design for Learning for children with special needs)?

In pre-test, participants were asked whether they know what WebQuest is. Among 28 participants, $85.7 \%$ of teachers do not know what WebQuest is, which is consistent with previous study done with Singapore special education teachers (Yang, Tzuo, \& Komara, 2011).

To answer research questions posed in the study, results of post-survey were summarized below.

Research question 1. Is WebQuest a useful tool to enhance teacher's higher order thinking, engagement, and creativity?

Among 28 participants, $89.88 \%$ of teachers thought that WebQuest has promoted their higher order abilities (28.57\% strongly agree, and $61.31 \%$ agree). In addition, $46.4 \%$ of teachers strongly agreed and $53.6 \%$ of teachers agree that WebQuest activities allowed them to be more motivated in learning and more engaged to a deeper level. All of the participants felt WebQuest fostered their creativity (53.6\% strongly agree and $46.4 \%$ agree) and have enjoyed and found it interesting (39.29\% strongly agree, and $55.36 \%$ agree).

Research Question 2. Does the use of WebQuest in teacher preparation foster stronger desires for teachers to integrate ICT in teaching? 
One hundred percent of teachers participated in our study agreed that WebQuest have helped teachers to learn more ways to incorporate technology in teaching and learning (71.4\% strongly agree, and $28.6 \%$ agree). They also expressed that after learning about the WebQuest in class, they would like to use more technology and web resources in teaching in the future (39.3\% strongly agree and $60.7 \%$ agree).

Research Question 3. Does WebQuest foster content-specific learning in teacher preparation (namely accommodating individual difference and implement Universal Design for Learning for children with special needs)?

Among 28 participants, 98.22\% found WebQuest helpful in accommodating individual differences and learning styles (strongly agree: $51.79 \%$; agree: $46.43 \%$ ). When asked whether WebQuest should be taught in teacher preparation programs as a teaching tool for accommodating individual differences, $67.90 \%$ of teachers strongly agree and $32.10 \%$ of teachers agree. In other words, special education teachers and early childhood teachers approved the value of teaching teachers to use WebQuest as a Universal Design for Learning tool for children with diverse learning styles and learning needs. Utilizing WebQuest to achieve curricular objective in early intervention was found to work based on teachers' ratings.

In order to test whether the training has an effect on students' learning and understanding about WebQuest as a pedagogical tool, paired sample t-test was employed. The mean for pre-test is 1.58 given that $85.7 \%$ of participants do not know about WebQuest and rated "Score 1: I don't know" as their answers in pre-test. After their learning experiences and training in creating WebQuests, the mean for the post test is 4.31 .

Based on SPSS paired sample t-test, there is a statistically significant difference between pre-tests and posttests $(\mathrm{t}=-12.59, \mathrm{p}<0.01)$. Participants rated the use of WebQuest significantly much higher $(\mathrm{M}=4.31)$ after experiencing WebQuest as users and were taught to create WebQuest as developers compared to pre-test. The results of the study concludes that the training on WebQuest demonstrated a statistically significant results for early childhood and special education teachers.

\section{CONCLUSION}

This study revealed promising results using WebQuest in teacher preparation for early childhood teachers and special education teachers in Singapore. In pre-test, $85.7 \%$ of teachers do not know what WebQuest is, which is consistent with previous study done with Singapore special education teachers (Yang, Tzuo, \& Komara, 2011). After the training on the WebQuest, participants found WebQuest beneficial in enhancing their critical thinking, motivation and engagement, and creativity. Participants were more inclined to integrate ICT in their teaching due to the training and exposure on the WebQuest. Moreover, WebQuest also helps the instructor to achieve contentspecific curricular objectives, namely Universal Design for Learning and accommodating children with special needs in mainstream classrooms.

For future studies, it would be valuable to further encourage teachers to use WebQuest in $\mathrm{P} / \mathrm{K}-12$ classrooms and conduct sub-studies on the implication of WebQuest in P/K-12 levels. The limitation of the study is the small sample size $(\mathrm{N}=28)$. Thus similar studies of larger scope are needed to draw stronger conclusions and make generalizations.

\section{AUTHOR INFORMATION}

Chien-Hui Yang is an assistant professor at National Institute of Education (NIE), Nanyang Technological University, Singapore. She obtained her doctorate in Early Childhood Special Education at University of Kansas at the United States. Chien-Hui taught at the Missouri State University at the United States for 3 years before joining NIE in 2005. Her research interests include early intervention, e-learning, ICT integration in education and teacher preparation, inclusion, teacher training, evidence based practices, and early childhood education. She has several research grants focusing on ICT integration in education and teacher preparation, early childhood education, and early intervention. E-mail: chienhui.yang@nie.edu.sg; chienyg@gmail.com (Corresponding author) 
Pei-Wen Tzuo is currently an assistant professor of Early Childhood and Special Needs Education at the National Institute of Education in Singapore. She received her Ph.D. from Indiana University- Bloomington in the US in 2004. After that, she returned to Taiwan where she taught in a reputed teacher education program before moving to Singapore. Her research interests include issues and trends of teacher education as well as globalization and diversity in education. E-mail: peiwen.tzuo@nie.edu.sg

Heidi J. Higgins is an Assistant Professor of Mathematics Education at the University of North Carolina Wilmington. Her primary research areas focus on the teaching and learning of mathematics in the elementary and middle school classrooms. She is currently working on research projects that focus on teaching mathematics for social equity, the impact of intellectual development on ability to implement best practices in teaching mathematics, and the use of technology to engage and motivate children to learn mathematics. E-mail: higginsh@uncw.edu

Clarence Tan is a Research Assistant with the Centre for Research in Pedagogy and Practice at the National Institute of Education (NIE), Singapore. Clarence obtained his BSc and BA specializing in Psychology and Education respectively from the University of New South Wales, Sydney. He also possesses CELTA certification from Cambridge ESOL. Clarence previously taught as a classroom teacher for three years before joining NIE. He is currently involved in a research project investigating the use of animated tutorials in student learning. E-mail: clarence.tan@nie.edu.sg

\section{REFERENCES}

1. Abbitt, J., \& Ophus, J. (2008). What we know about the impacts of WebQuests: A review of research. AACE Journal, 16(4), 441-456.

2. Abu-Elwan, R. (2007). The use of WebQuest to enhance the Mathematical Problem-Posing skills of preservice teachers. International Journal for Technology in Mathematics Education, 14(1), 31-39.

3. Allen, J., \& Street, M. (2007). The quest for deeper learning: An investigation into the impact of a knowledge-pooling WebQuest in primary initial teacher training. British Journal of Educational Technology, 38(6), 1102-1112.

4. Bates, A.J. (2008). Learning to design WebQuests: An exploration in social studies teacher education. Journal of Social Studies Research, 32(1), 10-21.

5. Bennett, C. (2001). Genres of research in multicultural education. Review of Educational Research, 71(2), 171-217.

6. Bielefeldt, T. (2001). Technology in teacher education. Journal of Computing in Teacher Education, 17(4), 4-15.

7. Biggs, J. (2003). Teaching for quality learning at university ( $2^{\text {nd }}$ ed.). Buckingham, UK: The Society for Research into Higher Education and Open University Press.

8. Chang, C.H. (2004, January). The Use of WebQuest as a Constructivist Learning Tool in Secondary School Geography in Singapore. Paper Presented AT 25th Annual National Educational Computing Conference, New Orleans.

9. Council for Exceptional Children. (2005). Universal Design for Learning: A guide for teachers and education professionals. Arlington, VA: Council for Exceptional Children.

10. Dixon, M., Stinson, M., Silver, R., Green, N.C., Nie, Y., Wright, S., Pak, S. \& Anand, M. (2008). A study on the Implementation of 'Strategies for Effective Engagement and Development' (SEED): Pilot and Development of Large Scale Grant Proposal. Singapore: National Institute of Education.

11. Dodge, B. (1995). Some thoughts about WebQuests. Retrieved March 19, 2009, from http://webquest.sdsu.edu/about webquests.html

12. Dodge, B. (2001). Five rules for writing a great WebQuest. Learning and Leading with Technology, 28(8), 6-9.

13. Ezell, D., Klein, C., Hines, R., \& Hall, S. (2003). Using WebQuest with students with disabilities, Center on Disabilities. Paper presented at Technology and Persons with Disabilities Conference. Retrieved March 19, 2009, from http://www.csun.edu/cod/conf/2003/proceedings/104.htm

14. Fisch, K., \& McLeod, S. (2007). Did you know? Retrieved March 19, 2009, from http://www.youtube.com 
15. Garry, G. (2001). Project-based learning just became easy: an introduction to WebQuest Learning Technology, 3(3). Retrieved March 19, 2009, from http://ltt.ieee.org/learn tech/issues/july2001/index.html

16. Gohagan, D. (1999). Computer Facilitated Instructional Strategies for Education: Designing WebQuests. Journal of Technology in Human Services, 16(2/3), 145-159.

17. Gulbahar, Yasemin (2008). Improving the technology integration skills of prospective teachers through practice: A case study. Turkish Online Journal of Educational Technology. 7(4), Article 8.6

18. Hassanien, A. (2006), Using Webquest to Support Learning with Technology in Higher Education'. Journal of Hospitality, Leisure, Sport \& Tourism Education (JoHLSTE), 5(1), 41-49.

19. Ikpeze, C. H., \& Boyd, F. B. (2007). Web-based inquiry learning: Facilitating thoughtful literacy with WebQuests. The Reading Teacher, 60(7), 644-654.

20. Kanuka, H., Rourke, L., \& Laflamme, E. (2007). The influence of instructional methods on the quality of online discussion. British Journal of Educational Psychology, 38(2), 260-271.

21. Kheng, P. C. (2003). Using WebQuest as a Tool to enhance Teaching. Paper presented at the ITE Teachers' Conference, Singapore.

22. Lahaie, U. D. (2008). Is nursing ready for WebQuest? Journal of Nursing Education, 47(12), 567-570.

23. Lara, S., \& Reparaz, Ch. (2005). Effectiveness of cooperative learning: WebQuest as a tool to produce scientific video. Retrieved March 19, 2009, from http://www.formatex.org/micte2005

24. Lamb, A., \& Teclehaimanot, B. (2005). A decade of WebQuests: A retrospective. In M. Orey, J. McClendon, \& R. M. Branch (Eds.), Educational media and technology year book (Vol. 30, pp. 81-101). Westport, CT: Libraries Unlimited.

25. Lenhart, A., Madden, M., Macgill, A. R., \& Smith, A. (2007). The use of social media gains a foothold in teen life as they embrace the conversational nature of interactive online media. Pew Internet \& American Life Project. Retrieved March 19, 2009 from http://www.pewinternet.org

26. Lim, C. P. (2006). The science and art of integrating ICT in Singapore schools. Singapore: iT21.

27. Lim, S., \& Hernandez, P. (2007). The WebQuest: An illustration of instructional technology implementation in MFT training. Contemporary Family Therapy, 29, 163-175.

28. Moursund D, Bielefeldt T. (1999). Will New Teachers Be Prepared to Teach in a Digital Age? A National Survey on Information Technology in Teacher Education. Santa Monica, CA: Milken Exchange on Education Technology.

29. Pellegrino, J.W., \& Altman, E.A. (1997). Information technology and teacher preparation: Some critical issues and illustrative solutions. Peabody Journal of Education, 72(1), 92-93.

30. Prensky, M. (2001). Digital natives, digital immigrants. On the Horizon, 9(5). Retrieved March 19, 2009, from http://www.marcprensky.com/writing/Prensky\%20\%20Digital\%20Natives, \%20Digital\%20Immigrants\%20 -\%20Part1.pdf

31. Schofield, J. W. (1995). Computers and classroom culture. New York: Cambridge University Press.

32. Richards, C. (2005). The design of effective ICT-supported learning activities: Exemplary models, changing requirements, and new possibilities. Language, Learning and Technology, 9(1), 60-79.

33. Rose, D. H., \& Meyer, A. (2002). Teaching every student in the digital age: Universal Design for Learning. Alexandria, VA: The Association for Supervision and Curriculum Development.

34. Rose., D. H., Meyer, A., \& Hitchcock, C. (Eds.). (2005). The universally designed classroom: Access curriculum and digital technologies. Cambridge, MA: Harvard Education Press.

35. Tan, J., \& Ng, P. T. (2005). Shaping Singapore's future: Thinking schools, Learning Nation. Singapore: Prentice Hall.

36. Wang, L., Ertmer, P. A., \& Newby, T. J. (2004). Increasing pre-service teachers' self-efficacy beliefs for technology integration. Journal of Research on Technology in Education, 36(3), 231-250.

37. Wheatley, K. F. (2003). Increasing computer use in early childhood teacher education: The Case of a "computer muddler." Contemporary Issues in Technology and Teacher Education [Online serial], 2(4). Retrieved March 19, 2009, from http://www.citejournal.org/vol2/iss4/general/article1.cfm

38. Widmer, C, \& Amburgey, V. (1994). Meeting technology guidelines for teacher preparation. Journal of Computing in Teacher Education, 10(2). 12-17.

39. Wild, M. (1995) Pre-service teacher education programmes for IT: an effective education?, Journal of Information Technology for Teacher Education, 4, 7-20. 
40. Wise, A. (1997). A message to NCATE institutions, board members, constituent organizations, and friends about Technology and the New Professional Teacher: Preparing for 21st Century Classrooms. Washington, DC: NCATE.

41. Wright, S., \& Gan, L. (2006). Nurturing innovation in Primary One classrooms through Early Childhood practices: Final Research Report. Singapore: EDRF, Ministry of Education.

42. Yang, C.-H., Tzuo, P. W., \& Komara, C. (2011). Using WebQuest as a Universal Design for Learning Tool to Enhance Teaching and Learning in Teacher Preparation Programs. Journal of College Teaching \& Learning, 8(3), 21-29. 